\title{
Toxicity and Antitumor Activity of a Thiophene-Acridine Hybrid
}

\author{
Thaís Lisboa ${ }^{1}$, Daiana Silva ${ }^{1}$, Sâmia Duarte ${ }^{1}$, Rafael Ferreira ${ }^{1}$, Camyla Andrade ${ }^{1}$,

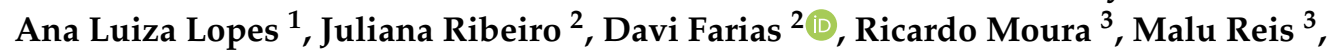 \\ Karina Medeiros ${ }^{4}$, Hemerson Magalhães ${ }^{1,5}$ and Marianna Sobral $1,5, *$ (D) \\ 1 Postgraduate Program in Bioactive Natural and Synthetic Products, Federal University of Paraíba, \\ 58051-970 João Pessoa, Paraíba, Brazil; thaismangeon@gmail.com (T.L.); daiana.frade@gmail.com (D.S.); \\ samiasduarte@gmail.com (S.D.); rafaelcarlos@ltf.ufpb.br (R.F.); camyla.andrade03@gmail.com (C.A.); \\ ana.lopes0407@gmail.com (A.L.L.); hemersoniury@gmail.com (H.M.) \\ 2 Laboratory for Risk Assessment of Novel Technologies, Department of Molecular Biology, \\ Federal University of Paraiba, Campus I, 58051-900 João Pessoa, Brazil; julianaacrs@hotmail.com (J.R.); \\ daviffarias@gmail.com (D.F.) \\ 3 Drug Development and Synthesis Laboratory, Department of Pharmacy, State University of Paraíba, \\ 58070-450 João Pessoa, PB, Brazil; ricardo.olimpiodemoura@gmail.com (R.M.); \\ malureis_farmacia@hotmail.com (M.R.) \\ 4 Department of Morphology, Federal University of Rio Grande do Norte, 59078-970 Natal, RN, Brazil; \\ karinapm@yahoo.com \\ 5 Department of Pharmaceutical Sciences, Federal University of Paraíba, 58051-970 João Pessoa, Paraíba, Brazil \\ * Correspondence: mariannavbs@gmail.com; Tel.: +55-83-98812-3555
}

Received: 2 December 2019; Accepted: 18 December 2019; Published: 24 December 2019

\begin{abstract}
The antitumor effects of thiophene and acridine compounds have been described; however, the clinical usefulness of these compounds is limited due to the risk of high toxicity and drug resistance. The strategy of molecular hybridization presents the opportunity to develop new drugs which may display better target affinity and less serious side effects. Herein, 2-((6-Chloro-2-methoxy-acridin-9-yl)amino)-5,6,7,8-tetrahydro-4H-cyclohepta[b]-thiophene-3-carbonitrile (ACS03), a hybrid thiophene-acridine compound with antileishmanial activity, was tested for toxicity and antitumor activity. The toxicity was evaluated in vitro (on HaCat and peripheral blood mononuclear cells) and in vivo (zebrafish embryos and acute toxicity in mice). Antitumor activity was also assessed in vitro in HCT-116 (human colon carcinoma cell line), K562 (chronic myeloid leukemic cell line), HL-60 (human promyelocytic leukemia cell line), HeLa (human cervical cancer cell line), and MCF-7 (breast cancer cell line) and in vivo (Ehrlich ascites carcinoma model). ACS03 exhibited selectivity toward HCT-116 cells (Half maximal inhibitory concentration, IC50 $=23.11 \pm 1.03 \mu \mathrm{M}$ ). In zebrafish embryos, ACS03 induced an increase in lactate dehydrogenase, glutathione S-transferase, and acetylcholinesterase activities. The LD50 (lethal dose 50\%) value in mice was estimated to be higher than $5000 \mathrm{mg} / \mathrm{kg}$ (intraperitoneally). In vivo, ACS03 $(12.5 \mathrm{mg} / \mathrm{kg}$ ) induced a significant reduction in tumor volume and cell viability. In vivo antitumor activity was associated with the nitric oxide cytotoxic effect. In conclusion, significant antitumor activity and weak toxicity were recorded for this hybrid compound, characterizing it as a potential anticancer compound.
\end{abstract}

Keywords: colorectal cancer; thiophene-acridine compound; antitumor; cytotoxicity; toxicity

\section{Introduction}

Cancer in the broader sense refers to more than 277 different types of cancer disease [1] and is a leading cause of death and disability, with 18.1 million people diagnosed globally and more than 
9.5 million deaths in 2018 [2]. Unfortunately, it shows disease variety at the tissue level, and this is a major challenge for its specific diagnosis and subsequent efficacy of treatment [3,4].

Acridines are interesting heterocyclic structures that are much-sought-after targets due to their broad biological properties since they are used as antitumor, antiparasitic, and antibacterial agents. For decades, they have been widely explored in the field of anticancer therapeutics, especially against leukemia $[5,6]$. These compounds, including amsacrine (m-AMSA), exhibit DNA-intercalating and topoisomerase-inhibiting activity $[7,8]$.

Thiophene constitutes a five-membered heterocyclic scaffold that contains sulfur, and it has attracted attention because of its presence in some marketed drugs including antiasthma, diuretic, antihistaminic, and anticancer drugs $[9,10]$. Thiophene compounds have been shown to exhibit cytotoxicity in several cancer cell lines [11,12]. The literature shows that these compounds may induce cell cycle arrest and apoptosis and affect tubulin polymerization [13].

Nevertheless, the clinical usefulness of acridine and thiophene compounds is limited due to the risk of high toxicity and drug resistance $[14,15]$. Moreover, the research and development of new alternatives for cancer treatment is necessary to provide a greater response to the tumor with less toxicity. The strategy of molecular hybridization has potential for the planning and development of new drugs. This technique is based on the combination of specific structural characteristics of different bioactive moieties to produce new compounds which may display better target affinity and biological efficacy, a modified selectivity profile, and less serious side effects, when compared to its precursors [5].

A new hybrid thiophene-acridine, 2-((6-Chloro-2-methoxyacridin-9-yl)amino)-5,6,7,8-tetrahydro$4 \mathrm{H}$-cyclohepta[b]-thiophene-3-carbonitrile (ACS03, Scheme 1), was previously synthesized. This compound showed antileishmanial activity and no cytotoxicity against erythrocytes. Additionally, other hybrid thiophene-acridine compounds have been characterized with the ability to interact with Leishmania DNA [16]. Then, considering the pharmacological potential of acridine and thiophene compounds, the present study aimed to investigate the toxicity and antitumor effect of the hybrid ACS03 on in vitro and in vivo models.

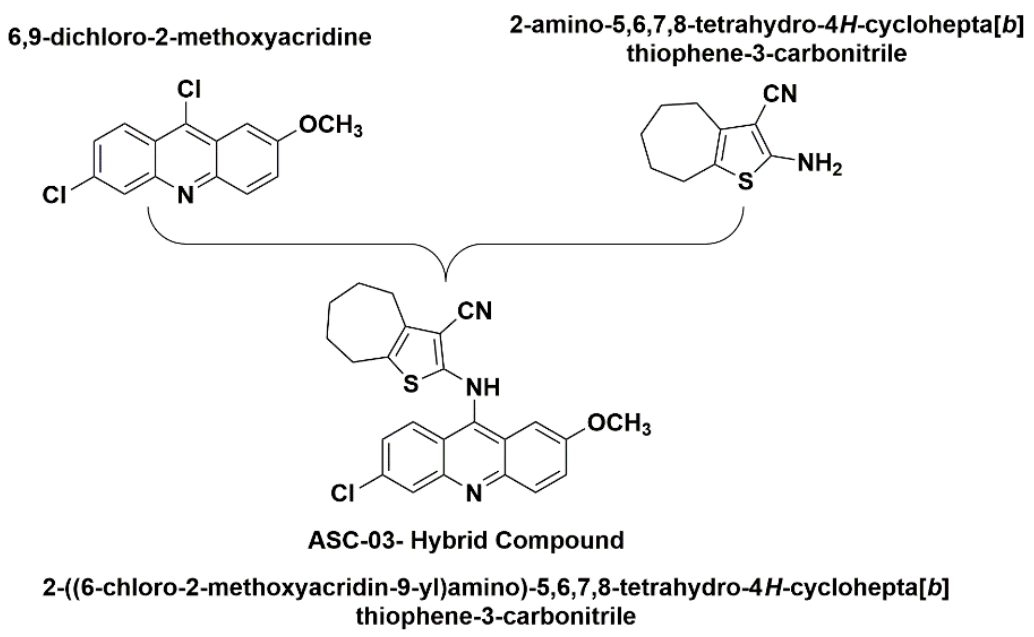

Scheme 1. Structures of 6,9-diclhoro-2-methoxyacridine, 2-amino-5,6,7,8-tetrahydro-4H-cyclohepta[b] thiophene-3-carbonitrile, and 2-((6-Chloro-2-methoxyacridin-9-yl)amino)-5,6,7,8-tetrahydro-4Hcyclohepta[b]-thiophene-3-carbonitrile (ACS03).

\section{Results}

\subsection{Cytotoxicity Assay}

ACS03 exhibited selectivity toward HCT-116 cells (human colon carcinoma cell line; IC50 $=23.11 \pm 1.03 \mu \mathrm{M}$ ), whereas no cytotoxicity was observed for other cell lines (IC50 $>50 \mu \mathrm{M}$ ). Doxorubicin was the positive control, with IC $50=2.59 \mu \mathrm{M}$ on HCT-116 cells. For the HaCat non-tumor 
cell line and peripheral blood mononuclear cells (PBMC), a lesser cytotoxic effect was observed (IC50 $=62.18 \pm 1.15 \mu \mathrm{M}$ and $115.2 \pm 5.82 \mu \mathrm{M}$, respectively) compared to HCT-116 cells (Table 1).

In addition, the cytotoxic effect of the ACS03 precursors was evaluated against HCT-116 cells. Higher cytotoxic activity of ACS03 compared to its precursors 2-amino-thiophene (IC50 > $1000 \mu \mathrm{M}$ ) and 6,9-diclhoro-2-methoxi-acridine (IC50 = 202.3 $\pm 1.19 \mu \mathrm{M}$ ) was observed.

Table 1. Cytotoxicity of ACS03 against various cell types by MTT (3-(4,5-dimethylthiazol-2-yl)-2,5diphenyltetrazolium bromide) assay. Mean IC50 (half maximal inhibitory concentration) values were calculated from cell growth curves $(n=3)$.

\begin{tabular}{cc}
\hline Cell Lines & ACS03 IC50 $(\mu \mathrm{M})$ \\
\hline HCT-116 & $23.11 \pm 1.03$ \\
HeLa & $>50$ \\
MCF-7 & $>50$ \\
K562 & $>50$ \\
HL-60 & $>50$ \\
HaCat & $62.18 \pm 1.15^{\mathrm{a}}$ \\
PBMC & $115.2 \pm 5.82^{\mathrm{a}}$ \\
\hline
\end{tabular}

\begin{abstract}
a Statistically significantly different from ACS03 treatment against HCT-116 cells $(p<0.05)$. Statistical analysis was performed using one-way ANOVA followed by Tukey's test. * HCT-116: human colon carcinoma cell line; HeLa: human cervical cancer cell line; MCF-7: breast cancer cell line; K562: chronic myeloid leukemic cell line; HL-60: human promyelocytic leukemia cell line; HaCat: Human immortalized keratinocytes cell line; PBMC: peripheral blood mononuclear cells.
\end{abstract}

\title{
2.2. Toxicity in Zebrafish Embryos
}

The toxicological evaluation in zebrafish embryos revealed that ACS03 did not present lethal effects during embryonic and larval development (LC50 higher than $1000 \mu \mathrm{M})$. In the morphological analysis of embryos, it was observed that ACS03 induced morphological changes in zebrafish embryos only at higher concentrations, such as spinal deformation $($ EC50 $=171.96 \mu \mathrm{M})$, reduction in larval length $(\mathrm{EC} 50=126.42 \mu \mathrm{M})$, and pericardial edema $(\mathrm{EC} 50>1000 \mu \mathrm{M})$.

\subsection{Biochemical Biomarkers in Zebrafish Embryos}

The effects of ACSO3 on the biomarker activities of LDH (Lactate dehydrogenase), GST (Glutathione S-transferase), and AChE (Acetylcholinesterase) in embryos are presented in Figure 1. ACS03 induced a significant increase in LDH activity (378.44 \pm 0.58 and $426.74 \pm 0.79$ at 20 and $40 \mu \mathrm{M}$, respectively; $p<0.05)$ compared to the control group $(316.6 \pm 1.28)$. In GST activity evaluation, an increase in a dose-dependent manner was observed $(57.96 \pm 0.23,75.83 \pm 0.13$, and $86.14 \pm 0.21$ at 10, 20, and $40 \mu \mathrm{M}$ ACS03, respectively; $p<0.05$ compared to the control group, $31.8 \pm 0.05$ ). In addition, ACS03 induced an increase in AChE activity at all doses tested $(85.67 \pm 0.11,94.59 \pm 0.20$, and $94.54 \pm 0.10$ at 10, 20, and $40 \mu \mathrm{M}$ ACS03, respectively; $p<0.05$ compared to the control group, $66.35 \pm 0.04$ ). 


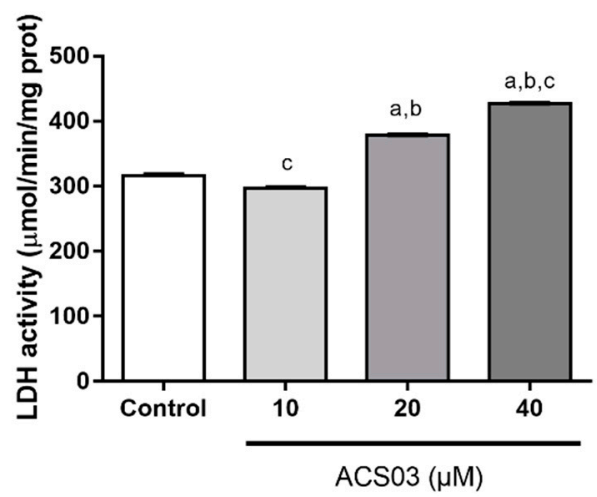

(a)

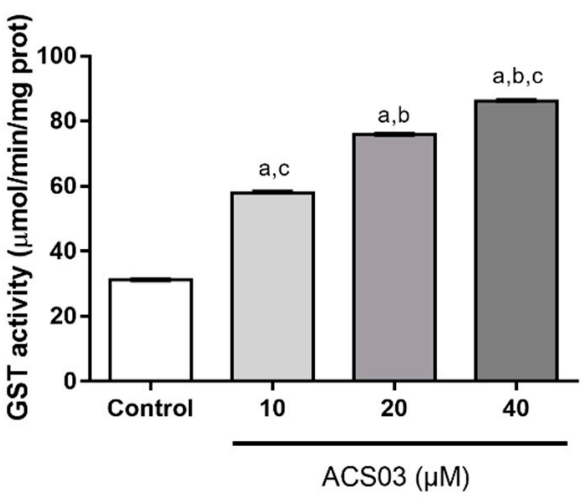

(b)

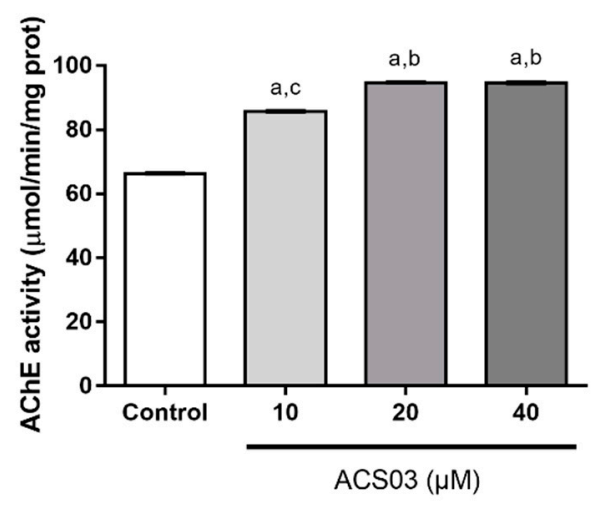

(c)

Figure 1. Biomarker activities (mean value \pm standard error) in zebrafish larvae after $96 \mathrm{~h}$ exposure to different concentrations of ACS03 $(n=4)$. (a) Lactate dehydrogenase (LDH) activity; (b) Glutathione S-transferase (GST) activity; (c) Acetylcholinesterase (AChE) activity. ${ }^{a} p<0.05$ compared to control group, ${ }^{\mathrm{b}} p<0.05$ compared to ACS03 $10 \mu \mathrm{M} .{ }^{\mathrm{c}} p<0.05$ compared to ACS03 $20 \mu \mathrm{M}$ (one-way ANOVA followed by Tukey's multiple comparison test, $p<0.05)$.

\subsection{Acute Preclinical Toxicity}

In the acute toxicity assay, no death was observed after the $300 \mathrm{mg} / \mathrm{kg}$ ACS03 treatment. Following Organization for Economic Co-operation and Development (OECD) guideline no. 423, the next step was to repeat the test. Again, no death was recorded. A new experiment was carried out twice with a dose of $2000 \mathrm{mg} / \mathrm{kg}$. ACS03 did not induce death in any of the experimental animals. The LD50 (lethal dose $50 \%$ ) value was estimated to be higher than $5000 \mathrm{mg} / \mathrm{kg}$.

\subsection{In Vivo Antitumor Activity}

ACS03 $(12.5 \mathrm{mg} / \mathrm{kg})$ significantly reduced tumor volume $(0.0 \mathrm{~mL} ; p<0.05)$ and cell viability $\left(4.12 \pm 1.28 \times 10^{6}\right.$ cells $\left./ \mathrm{mL} ; p<0.05\right)$, compared to the control group $(6.93 \pm 0.79 \mathrm{~mL}$ and $115.5 \pm 23.97 \times 10^{6}$ cells $/ \mathrm{mL}$, respectively) (Figure 2). Similar results were observed for 5-fluorouracil (5-FU). 


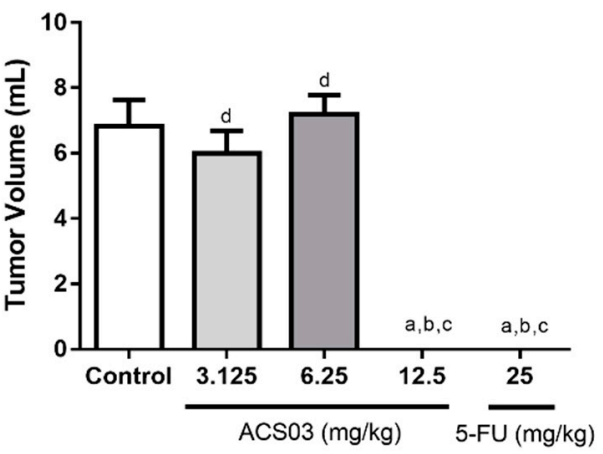

(a)

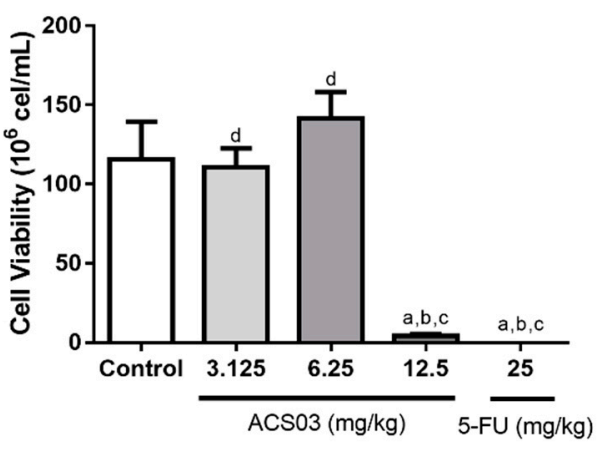

(b)

Figure 2. Effect of $\operatorname{ACS} 03(3.125,6.25$, or $12.5 \mathrm{mg} / \mathrm{kg}$ ) on (a) tumoral volume and (b) cell viability. Data are presented as mean \pm standard error of mean (SEM) of six animals analyzed by analysis of variance (ANOVA) followed by Tukey's test. ${ }^{\mathrm{a}} p<0.05$ compared to tumor control group, ${ }^{\mathrm{b}} p<0.05$ compared to $3.125 \mathrm{mg} / \mathrm{kg}$ dose. ${ }^{\mathrm{c}} p<0.05$ compared to compared to $6.25 \mathrm{mg} / \mathrm{kg}$ dose. ${ }^{\mathrm{d}} p<0.05$ compared to compared to $12.5 \mathrm{mg} / \mathrm{kg}$ dose.

\subsection{Quantification of Nitrite Levels}

ACS03 $(12.5 \mathrm{mg} / \mathrm{kg})$ induced a significant increase in nitrite concentration $(188.5 \pm 7.98 \mu \mathrm{M}$; $p<0.05)$ as compared to the control group $(36.09 \pm 0.72 \mu \mathrm{M})$ (Figure 3). 5 -FU ( $25 \mathrm{mg} / \mathrm{kg}$ ) induced no significant change in nitrite concentration $(16.3 \pm 2.91 \mu \mathrm{M})$.

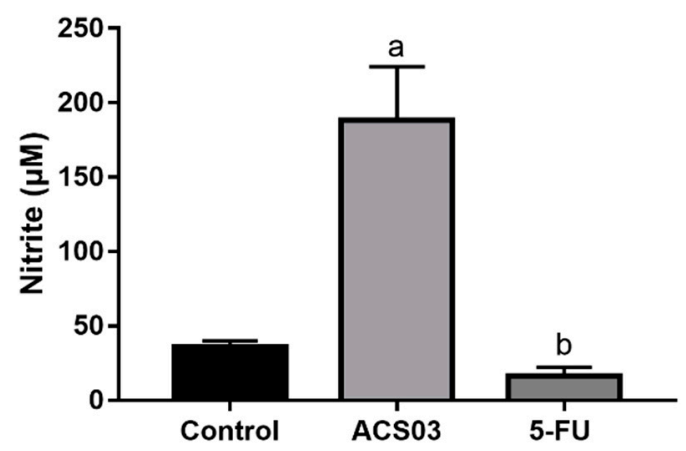

Figure 3. Effect of ACS03 $(12.5 \mathrm{mg} / \mathrm{kg})$ and $5-\mathrm{FU}(25 \mathrm{mg} / \mathrm{kg})$ on quantification of nitrite in the peritoneal fluid of Ehrlich ascites carcinoma transplanted mice. Data are presented as mean \pm SEM of six animals analyzed by analysis of variance (ANOVA) followed by Tukey's test. ${ }^{a} p<0.05$ compared to tumor control group. ${ }^{\mathrm{b}} p<0.05$ compared to ACS03.

\section{Discussion}

The discovery of novel anticancer drugs is critical for pharmaceutical research and development and patient treatment [17]. In this study, we investigated the in vitro and in vivo anticancer activity and toxicity of a new thiophene-acridine hybrid, ACS03.

The in vitro antitumor activity of ACS03 was evaluated against different human tumor cell lines. Our data show that ACS03 has a selective effect against colorectal carcinoma cells HCT-116. Colorectal carcinoma is the second leading cause of cancer-related deaths in the world and the third most common cause of cancer-related death in the United States $[18,19]$. Therefore, it is indispensable to discover new compounds for its prevention and treatment [20]. Literature reports have shown the antitumor activity of acridine and thiophene compounds against colorectal carcinoma cells [6,21]. However, the precursor acridine and thiophene compounds were also tested against HCT-116 cells, and very low cytotoxicity was observed. These results indicate that hybridization of the thiophene and acridine 
nuclei was effective in increasing the antitumor activity above that of the separate compounds. This is the first time that a hybrid thiophene-acridine compound with antitumor activity has been described.

The clinical use of acridine and thiophene compounds is limited by problems such as side effects, drug resistance, and low bioavailability, which have encouraged further modifications of these compounds [14,22]. Previous data have shown cytotoxicity of acridine compounds, including amsacrine, against peripheral blood mononuclear cells (PBMC) [23]. Similarly, the high toxicity described for thiophene compounds against normal cells has limited their utility [24]. Herein, the hybrid ACS03 produced low cytotoxicity against non-tumor HaCat and PBMC cells, suggesting that the balance between antitumor activity and toxicity is favorable for its therapeutic application.

Embryonic and larval Danio rerio (zebrafish) have previously been used as a toxicological model to conduct rapid tests and developmental toxicity assays, including toxicity assessment of pharmaceutical compounds [25]. Fortunately, many toxic responses have been conserved between zebrafish and human toxicological studies [26-28]. Therefore, zebrafish embryos are valuable in the assessment of system toxicity, which can be evaluated using overall embryonic mortality as a measure from which the working range of a compound can be determined [29]. In this study, we showed that ACS03 did not induce mortality of fish embryos and larvae; however, the embryos presented some morphological changes like spinal deformation, reduction in larval length, and pericardial edema. Nevertheless, these morphological changes occurred at concentrations 5 times higher than the IC50 of ACS03 on HCT-116 cells. Several reports also support the idea that zebrafish is a very sensitive model of toxicity evaluation, and early stages are commonly the most sensitive to chemical exposure [30].

We also analyzed the enzymatic activity in zebrafish larvae (lactate dehydrogenase (LDH), glutathione S-transferase (GST), and acetylcholinesterase (AChE) activities). LDH is a metabolic enzyme involved in the anaerobic pathway of carbohydrate metabolism, and it has been used as a biomarker of stress in fish [31]. ACS03 increased the LDH activity, showing that there was a high energy requirement in zebrafish larvae exposed to the treatment. AChE is responsible for the enzymatic degradation of acetylcholine (ACh), and its absence or low activity causes high levels of systemic ACh, which acts as a neurotransmitter [32]. Herein, we observed an increase in AChE activity, which is in general associated to neurotoxicity [33]; however, the literature also suggests that AChE may display antitumor activity, in addition to correlating tumor malignancy with low activity of AChE [34-36]. GSTs are vital in the Phase II detoxification enzymes pathway in humans, and they provide protection against toxins by catalyzing toxin conjugation with Glutathione (GSH) or passively binding to various exogenous/endogenous toxic molecules, including environmental toxins, carcinogens, chemotherapeutic agents, and products of oxidative stress $[37,38]$. We showed an increase in GST activity in larvae exposed to ACS03; this may be associated with antioxidant capacity increase.

In vivo preclinical toxicological analysis was performed in mice to determine safe doses to be used for pharmacological tests. Considering the high LD50 $(5000 \mathrm{mg} / \mathrm{kg})$ estimated, ACS03 has low toxicity. If the LD50 of the test substance is 3 times more than the minimum effective dose, the substance is considered a good candidate for further studies [39].

To evaluate the in vivo antitumor effect of ACS03, we used the Ehrlich ascites carcinoma (EAC) model, a spontaneous murine mammary adenocarcinoma that is a well-established model for testing new drugs [40,41]. ACS03 reduced the tumor volume and cell viability, indicating significant in vivo activity of this compound. Our data corroborate the literature results of separate acridine and thiophene compounds showing an antitumor effect on the Ehrlich ascites carcinoma model [42,43].

Oxide nitric (NO) is a ubiquitous, water-soluble, free radical gas which plays a key role in various physiological and pathological processes, including cancer. Literature reports have indicated that NO may have dual effects in cancer [44]: At low concentration, NO causes tumor progression in antiapoptotic, pro-growth, and proangiogenic ways. On the other hand, at high concentrations, NO has a potential role in cancer therapy by inducing proapoptotic and antiangiogenic effects and inhibition of proliferation [45]. In the Ehrlich ascites carcinoma model, we demonstrated that ACS03 treatment 
induced a significant increase in nitrite levels, which is associated with increased NO levels, suggesting that the ACS03 mechanism of antitumor action involves NO cytotoxic effects.

In conclusion, our findings suggest that thiophene-acridine hybrid ACS03 has potential antitumor activity and low toxicity, and it has potential as an anticancer compound.

\section{Materials and Methods}

\subsection{Treatment}

ACS03 was provided by Dr. Ricardo Olimpio de Moura from the Laboratory of Synthesis and Vectorization of Molecules (LSVM) of the State University of Paraíba (UEPB), João Pessoa, Brazil, and it was synthesized as described previously [16]. For in vitro assays, ACS03 was dissolved in $100 \%$ DMSO and added to the culture medium at a final concentration of $0.5 \%$. For in vivo assay, ACS03 was dissolved in $12 \%(\mathrm{v} / \mathrm{v})$ Tween 80 in saline.

\subsection{Cell Lines}

Colorectal carcinoma cells (HCT-116), chronic myelogenous leukemia (K562), and acute promyelocytic leukemia (HL-60) were generously provided by Dr. Manoel de Moraes (Federal University of Ceará, Fortaleza, Brazil) and cultured in Roswell Park Memorial Institute 1640 (RPMI 1640; Sigma Aldrich, St. Louis, MO, USA) medium supplemented with $10 \%$ fetal bovine serum (GIBCO, Grand Island, NY, USA) and 1\% penicillin-streptomycin (Sigma Aldrich, St. Louis, MO, USA). Human keratinocyte cells (HaCaT; provided by Dr. Jaciana Aguiar from Federal University of Pernambuco, Recife, Pernambuco, Brazil), cervical cancer cells (HeLa; purchased from the cell bank of Rio de Janeiro, Rio de Janeiro, Brazil), and breast cancer cells (MCF-7; provided by Dr. João Ernesto de Carvalho from University of Campinas, Campinas, São Paulo, Brazil) were grown and maintained in Dulbecco's Modified Eagle's Medium (DMEM; Sigma Aldrich, St. Louis, MO, USA) supplemented with $10 \%$ fetal bovine serum (GIBCO, Grand Island, NY, USA) and 1\% penicillin-streptomycin (Sigma Aldrich, St. Louis, MO, USA). All cell types were maintained in $5 \% \mathrm{CO}_{2}$ at $37^{\circ} \mathrm{C}$ with humidity.

Ehrlich ascites carcinoma was generously provided by Pharmacology and Toxicology Division, CPQBA, UNICAMP (Paulínia, São Paulo, Brazil). The cells were maintained in the peritoneal cavities of Swiss mice in the Dr. Thomas George Bioterium (Research Institute in Drugs and Medicines/Federal University of Paraíba, João Pessoa, Brazil).

\subsection{Peripheral Blood Mononuclear Cells (PBMC)}

Heparinized blood was collected from healthy donors, and the PBMC were isolated by a standard method of density-gradient centrifugation using Ficoll-Histopaque (Sigma Aldrich, St. Louis, MO, USA). PBMC were cultivated in RPMI-1640 medium supplemented with $10 \%$ fetal bovine serum, $1 \%$ penicillin-streptomycin, and $2 \%$ phytohaemagglutinin. Cells were kept at $37^{\circ} \mathrm{C}$ with $5 \% \mathrm{CO}_{2}$ for $24 \mathrm{~h}$ before the start of the experiment. This study was approved by the Ethics Committee of the Human Health Sciences Center Research (CCS), UFPB (CAAE: 22986519.0.0000.5188), Brazil.

\subsection{Zebrafish Embryos}

The zebrafish (Danio rerio) embryos were provided by the zebrafish facility established at Department of Molecular Biology, Federal University of Paraíba (João Pessoa, Brazil). To obtain embryos, an egg trap was placed overnight in a tank containing male and female specimens (1:1 ratio) of a wild-type strain one day prior to testing. One hour after the beginning of the light cycle (14 h light/10 h dark), eggs were collected and rinsed with E3 medium $(5 \mathrm{mM} \mathrm{NaCl}, 0.17 \mathrm{mM} \mathrm{KCl}$, $0.33 \mathrm{mM} \mathrm{CaCl}_{2}$, and $0.33 \mathrm{mM} \mathrm{MgSO}_{4}$ ). Viable fertilized eggs were selected using a stereomicroscope (80× magnification), and embryotoxicity analysis was carried out. All experiments were approved by the Committee on Ethical Use of Animals in Research (CEUA) of Federal University of Paraíba, Brazil, certified by number 5900310718/2018. 


\subsection{Animals}

Female Swiss albino mice (Mus musculus) weighing between 28 and $32 \mathrm{~g}$, with an approximate age of 60 days and obtained from the Dr. Thomas George Bioterium (Research Institute in Drugs and Medicines/Federal University of Paraíba, Paraíba, Brazil) were used. The animals were grouped in polyethylene cages containing six animals, with free access to food (Purina ${ }^{\circledR}$ feed pellets, St. Louis, MO, USA) and water. The animals were kept under controlled conditions $\left(21 \pm 1{ }^{\circ} \mathrm{C}, 12 \mathrm{~h} / 12 \mathrm{~h}\right.$ off light/dark cycle). All experiments were approved by the Committee on Ethical Use of Animals in Research (CEUA) of Federal University of Paraíba, Brazil, certified by number 093/2017.

\subsection{In Vitro Assay}

\section{Cell Viability Assay}

MTT (3-(4,5-dimethylthiazol-2-yl)-2,5-diphenyltetrazolium bromide) reduction assay was used to evaluate the cytotoxicity of ACS03 and its precursors (2-amino-5,6,7,8-tetrahydro-4Hcyclohepta[b]thiophene-3-carbonitrile and 6,9-dichloro-2-methoxyacridine) against tumor and non-tumor cell lines and PBMC. For the MTT assay, cell lines $\left(3 \times 10^{5}\right.$ cells $\left./ \mathrm{mL}\right)$ and PBMC $\left(1 \times 10^{6}\right.$ cells $\left./ \mathrm{mL}\right)$ were seeded on 96-well plates and cultured for $24 \mathrm{~h}$. ACS03 $(3.125-200 \mu \mathrm{M})$ was added to the cell cultures and incubated for $72 \mathrm{~h}$. After incubation, $110 \mu \mathrm{L}$ of the supernatant was removed and $10 \mu \mathrm{L}$ of the MTT reagent (Sigma Aldrich, St. Louis, MO, USA) was added to each well, and the plates were then incubated at $37^{\circ} \mathrm{C}$. Following $3 \mathrm{~h}$ incubation, $100 \mu \mathrm{L}$ of sodium dodecyl sulfate (SDS) was added to dissolve the formazan crystals produced and left overnight to incubate [46]. The amount of formazan is proportional to the number of viable cells present. The optical density was measured using a microplate spectrophotometer reader (Microplate reader BioTek Instruments, Sinergy HT, Winooski, VT, USA) at $\lambda=570 \mathrm{~nm}$ and used to calculate the IC50 (half maximal inhibitory concentration).

\subsection{In Vivo Assays}

\subsubsection{Acute Toxicity Test Using Zebrafish Embryos}

The fish embryo acute toxicity (FET) test was conducted with ACS03 according to OECD's guideline no. 236, with slight modifications [47]. Zebrafish embryos of up to 3 hpf (hours post fertilization) of age were initially exposed to 250-15.62 $\mu \mathrm{M}$. For each concentration tested, we prepared a 96-well plate containing 20 fertilized eggs ( 1 embryo per well) exposed to the test sample and 4 embryos exposed only to E3 medium (internal controls). The exposure was performed for $96 \mathrm{~h}$, and the embryos were analyzed every $24 \mathrm{~h}$ for the apical endpoints: egg coagulation; lack of somite formation; lack of detachment of the tail-bud from the yolk sac; and lack of heartbeat. In the presence of any of these endpoints, the embryo/larva was considered dead. The number of deaths was used to calculate the LC50 (median lethal concentration). Sublethal effects were also recorded in order to obtain the EC50 (median effect concentration), them being spinal deformation, reduction in larval length, and pericardial edema. The exposures were under static conditions (without renovation of test sample or E3 medium). Observations were performed in a stereomicroscope (80× magnification) and photographed (Zeiss). After 96 h, surviving larvae were euthanized with eugenol and properly discarded.

\subsubsection{Enzyme Testing Using Zebrafish Larvae}

The FET test was repeated for ACS03 under the same conditions described above, but this time the embryos were independently exposed to three concentrations $(10,20$, and $40 \mu \mathrm{M})$. At the end of the exposure period $(96 \mathrm{~h})$, the larvae were quickly frozen in a ratio of 1 larva per $100 \mu \mathrm{L}$ of $0.1 \mathrm{M}$ sodium phosphate buffer, $\mathrm{pH} 7.4$.

Larval groups from each of the three tested concentrations and a negative control group (exposed to E3 medium only) were macerated using $1: 9(\mathrm{w} / \mathrm{v})$ cold $0.9 \% \mathrm{NaCl}$ solution. The homogenates 
were centrifuged at $10,000 \times g$ for $10 \mathrm{~min}$ at $4{ }^{\circ} \mathrm{C}$, and the resulting supernatants were used for the measurement of soluble protein content and enzyme activity. The activities of acetylcholinesterase (AChE), glutathione S-transferase (GST), and lactate dehydrogenase (LDH) were measured according to Domingues et al. (2010) [48]. Tests were done in quadruplicate for each enzyme.

\subsubsection{Assessment of Acute Preclinical Toxicity in Mice}

The acute toxicity test in mice was performed according to the Guideline for Testing of Chemicals no. 423 of the Organization for Economic Co-operation and Development (OECD) [49]. Mice were divided into different groups ( $n=3$ females/group). The control group received vehicle alone ( $12 \%$ (v/v) Tween 80 in saline), and ACS03 was tested in single doses of 300 or $2000 \mathrm{mg} / \mathrm{kg}$, intraperitoneally (i.p.). The dose responsible for the death of $50 \%$ of the experimental animals (LD50) was estimated.

\subsubsection{Evaluation of In Vivo Antitumor Activity in the Ehrlich Ascites Carcinoma Model}

Mice were inoculated with $4 \times 10^{6}$ cells $/ \mathrm{mL}$ of Ehrlich tumor cells $(0.5 \mathrm{~mL} /$ animal), intraperitoneally (i.p.) [50]. After $24 \mathrm{~h}$, mice were divided into five groups ( $n=6 /$ group) and treated with vehicle alone (12\% (v/v) Tween 80 in saline), 5-FU (standard drug, $25 \mathrm{mg} / \mathrm{kg}$ ), or ACS03 $(3.125,6.25,12.5$, or $25 \mathrm{mg} / \mathrm{kg}$ ) for seven consecutive days (i.p.). On the ninth day, all animals were anesthetized with ketamine hydrochloride (100 mg/kg), intramuscularly (i.m.) and xylazine hydrochloride (16 mg/k) intraperitoneally (i.p.) and were euthanized by cervical dislocation. The volume of ascitic fluid was collected from the peritoneal cavity to determine the tumor volume $(\mathrm{mL})$. Trypan blue assay was used to evaluate the cell viability [51].

\subsubsection{Quantification of Nitrite Levels in the Ehrlich Ascites Carcinoma Model}

The nitrite concentration in the ascitic fluid was measured using Griess reagent [52]. For this, the peritoneal fluid of control and treated animals $(12.5 \mathrm{mg} / \mathrm{kg}$ ACSO3 and $25 \mathrm{mg} / \mathrm{kg} 5-\mathrm{FU})$ was used. The optical density was measured using a microplate spectrophotometer reader (Microplate reader BioTek Instruments, Sinergy HT, Winooski, VT, USA) at $\lambda=560 \mathrm{~nm}$. Concentrations of nitrite were calculated from a standard curve previously established with known molar concentrations of sodium nitrite. The tests were done in quadruplicate and the values expressed in $\mu \mathrm{M}$ [51].

\subsection{Statistical Analysis}

The results are expressed as the mean \pm SEM. Statistical analysis of data was performed using analysis of variance (ANOVA), followed by Tukey's test $(p<0.05)$. For zebrafish embryo cytotoxicity, the median lethal concentration (LC50) values and the median effect concentration (EC50) values were calculated by probit regression analysis [53].

Author Contributions: T.L., D.S., S.D., R.F., C.A., A.L.L., J.R., D.F., R.M., M.R., K.M., H.M. and M.S. designed and performed the experiments, and analyzed the data. R.M. and M.R. synthesized and provided the ACS03. T.L. and M.S. wrote the paper. All authors have read and agreed to the published version of the manuscript.

Funding: The Coordenação de Aperfeiçoamento de Pessoal de Nível Superior-Brasil (CAPES)-Finance Code 001and CNPq partly financed this study. This research received no external funding.

Conflicts of Interest: Authors declare no conflict of interest.

\section{References}

1. Hassanpour, S.H.; Dehghani, M. Review of cancer from perspective of molecular. J. Cancer Res. Pract. 2017, 4, 127-129. [CrossRef]

2. Cancer Today. Cancer Fact Sheets. Available online: https://gco.iarc.fr/today/fact-sheets-cancers (accessed on 4 November 2019).

3. Meacham, C.E.; Morrison, S.J. Tumour heterogeneity and cancer cell plasticity. Nature 2013, 501, $328-337$. [CrossRef] 
4. Fisher, R.; Pusztai, L.; Swanton, C. Cancer heterogeneity: Implications for targeted therapeutics. Br. J. Cancer 2013, 108, 479-485. [CrossRef]

5. Zhang, B.; Li, X.; Li, B.; Gao, C.; Jiang, Y. Acridine and its derivatives: A patent review (2009-2013). Expert Opin. Ther. Pat. 2014, 24, 647-664. [CrossRef]

6. Belmont, P.; Bosson, J.; Godet, T.; Tiano, M. Acridine and acridone derivatives, anticancer properties and synthetic methods: Where are we now? Anti-Cancer Agents Med. Chem. 2007, 7, 139-169. [CrossRef]

7. Crenshaw, J.M.; Graves, D.E.; Denny, W.A. Interactions of acridine antitumor agents with DNA: Binding energies and groove preferences. Biochemistry 1995, 34, 13682-13687. [CrossRef]

8. Kao-Shan, C.S.; Micetich, K.; Zwelling, L.A.; Whang-Peng, J. Cytogenetic effects of amsacrine on human lymphocytes in vivo and in vitro. Cancer Treat. Rep. 1984, 68, 989-997.

9. Gramec, D.; Peterlin Mašič, L.; Sollner Dolenc, M. Bioactivation potential of thiophene-containing drugs. Chem. Res. Toxicol. 2014, 27, 1344-1358. [CrossRef] [PubMed]

10. Joshi, E.M.; Heasley, B.H.; Chordia, M.D.; Macdonald, T.L. In vitro metabolism of 2-acetylbenzothiophene: Relevance to zileuton hepatotoxicity. Chem. Res. Toxicol. 2004, 17, 137-143. [CrossRef] [PubMed]

11. Romagnoli, R.; Baraldi, P.G.; Lopez-Cara, C.; Salvador, M.K.; Preti, D.; Tabrizi, M.A.; Balzarini, J.; Nussbaumer, P.; Bassetto, M.; Brancale, A.; et al. Design, synthesis and biological evaluation of 3,5-disubstituted 2-amino thiophene derivatives as a novel class of antitumor agents. Bioorg. Med. Chem. 2014, 22, 5097-5109. [CrossRef] [PubMed]

12. Ghorab, M.M.; Bashandy, M.S.; Alsaid, M.S. Novel thiophene derivatives with sulfonamide, isoxazole, benzothiazole, quinoline and anthracene moieties as potential anticancer agents. Acta Pharmaceutica 2014, 64, 419-431. [CrossRef] [PubMed]

13. Dos Santos, F.A.; Pereira, M.C.; De Oliveira, T.B.; Mendonça, F.J.B.; Do Carmo Alves De Lima, M.; Da Rocha Pitta, M.G.; Da Rocha Pitta, I.; De Melo Rêgo, M.J.B.; Da Rocha Pitta, M.G. Anticancer properties of thiophene derivatives in breast cancer MCF-7 cells. Anti-Cancer Drugs 2017, 29, 157-166. [CrossRef] [PubMed]

14. Zhao, M.; Cui, Y.; Zhao, L.; Zhu, T.; Lee, R.J.; Liao, W.; Sun, F.; Li, Y.; Teng, L. Thiophene derivatives as new anticancer agents and their therapeutic delivery using folate receptor-targeting nanocarriers. ACS Omega 2019, 4, 8874-8880. [CrossRef] [PubMed]

15. Gensicka-Kowalewska, M.; Cholewiński, G.; Dzierzbicka, K. Recent developments in the synthesis and biological activity of acridine/acridone analogues. RSC Adv. 2017, 7, 15776-15804. [CrossRef]

16. De Lima Serafim, V.; Félix, M.B.; Frade Silva, D.K.; da Rodrigues, K.A.F.; Andrade, P.N.; de Almeida, S.M.V.; de Albuquerque dos Santos, S.; de Oliveira, J.F.; do Carmo Alves de Lima, M.; Mendonça-Junior, F.J.B.; et al. New thiophene-acridine compounds: Synthesis, antileishmanial activity, DNA binding, chemometric, and molecular docking studies. Chem. Biol. Drug Des. 2018, 91, 1141-1155. [CrossRef]

17. Sun, J.; Wei, Q.; Zhou, Y.; Wang, J.; Liu, Q.; Xu, H. A systematic analysis of FDA-approved anticancer drugs. BMC Syst. Biol. 2017, 11, 87-104. [CrossRef]

18. Siegel, R.; Naishadham, D.; Jemal, A. Cancer statistics, 2013. CA Cancer J. Clin. 2013, 63, 11-30. [CrossRef]

19. Chen, C.C.; Neugut, A.I.; Rotterdam, H. Risk factors for adenocarcinomas and malignant carcinoids of the small intestine: Preliminary findings. Cancer Epidemiol. Biomark. Prev. 1994, 3, 205-209.

20. Logan, I.E.; Miranda, C.L.; Lowry, M.B.; Maier, C.S.; Stevens, J.F.; Gombart, A.F. Antiproliferative and cytotoxic activity of xanthohumol and its non-estrogenic derivatives in colon and hepatocellular carcinoma cell lines. Int. J. Mol. Sci. 2019, 20, 1203. [CrossRef]

21. Fu, W.; Li, X.; Lu, X.; Zhang, L.; Li, R.; Zhang, N.; Liu, S.; Yang, X.; Wang, Y.; Zhao, Y.; et al. A novel acridine derivative, LS-1-10 inhibits autophagic degradation and triggers apoptosis in colon cancer cells. Cell Death Dis. 2017, 8, 3086-3099. [CrossRef]

22. Sánchez, I.; Reches, R.; Caignard, D.H.; Renard, P.; Pujol, M.D. Synthesis and biological evaluation of modified acridines: The effect of $\mathrm{N}$ - and $\mathrm{O}-$ substituent in the nitrogenated ring on antitumor activity. Eur. J. Med. Chem. 2006, 41, 340-352. [CrossRef] [PubMed]

23. Barros, F.W.A.; Silva, T.G.; Da Rocha Pitta, M.G.; Bezerra, D.P.; Costa-Lotufo, L.V.; De Moraes, M.O.; Pessoa, C.; De Moura, M.A.F.B.; De Abreu, F.C.; De Lima, M.D.C.A.; et al. Synthesis and cytotoxic activity of new acridine-thiazolidine derivatives. Bioorganic Med. Chem. 2012, 20, 3533-3539. [CrossRef] [PubMed]

24. Véras of Aguiar, A.C.; Of Moura, R.O.; Bezerra Mendonça, J.F.; de Oliveira Rocha, H.A.; Gomes Câmara, R.B.; dos Santos Carvalho Schiavon, M. Evaluation of the antiproliferative activity of 2-amino thiophene derivatives against human cancer cells lines. Biomed. Pharmacother. 2016, 84, 403-414. [CrossRef] [PubMed] 
25. Hill, A.J.; Teraoka, H.; Heideman, W.; Peterson, R.E. Zebrafish as a model vertebrate for investigating chemical toxicity. Toxicol. Sci. 2005, 86, 6-19. [CrossRef] [PubMed]

26. Bambino, K.; Chu, J. Zebrafish in toxicology and environmental health. Curr. Top. Dev. Biol. 2017, 124, 331-367.

27. Ducharme, N.A.; Reif, D.M.; Gustafsson, J.A.; Bondesson, M. Comparison of toxicity values across zebrafish early life stages and mammalian studies: Implications for chemical testing. Reprod. Toxicol. 2015, 55, 3-10. [CrossRef]

28. Sipes, N.S.; Padilla, S.; Knudsen, T.B. Zebrafish-As an integrative model for twenty-first century toxicity testing. Birth Defects Res. Part C Embryo Today Rev. 2011, 93, 256-267. [CrossRef]

29. Huiting, L.N.; Laroche, F.; Feng, H. The zebrafish as a tool to cancer drug discovery. Austin J. Pharmacol. Ther. 2015, 3, 1069-1087.

30. Hallare, A.V.; Köhler, H.R.; Triebskorn, R. Developmental toxicity and stress protein responses in zebrafish embryos after exposure to diclofenac and its solvent, DMSO. Chemosphere 2004, 56, 659-666. [CrossRef]

31. Vieira, L.R.; Sousa, A.; Frasco, M.F.; Lima, I.; Morgado, F.; Guilhermino, L. Acute effects of Benzo[a]pyrene, anthracene and a fuel oil on biomarkers of the common goby Pomatoschistus microps (Teleostei, Gobiidae). Sci. Total Environ. 2008, 395, 87-100. [CrossRef]

32. Dvir, H.; Silman, I.; Harel, M.; Rosenberry, T.L.; Sussman, J.L. Acetylcholinesterase: From 3D structure to function. Chem. Biol. Interact. 2010, 187, 10-22. [CrossRef] [PubMed]

33. Kais, B.; Stengel, D.; Batel, A.; Braunbeck, T. Acetylcholinesterase in zebrafish embryos as a tool to identify neurotoxic effects in sediments. Environ. Sci. Pollut. Res. 2015, 22, 16329-16339. [CrossRef] [PubMed]

34. Pérez-Aguilar, B.; Vidal, C.J.; Palomec, G.; García-Dolores, F.; Gutiérrez-Ruiz, M.C.; Bucio, L.; Gómez-Olivares, J.L.; Gómez-Quiroz, L.E. Acetylcholinesterase is associated with a decrease in cell proliferation of hepatocellular carcinoma cells. Biochimica et Biophysica Acta Mol. Basis Dis. 2015, 1852, 1380-1387. [CrossRef] [PubMed]

35. Xu, H.; Shen, Z.; Xiao, J.; Yang, Y.; Huang, W.; Zhou, Z.; Shen, J.; Zhu, Y.; Liu, X.-Y.; Chu, L. Acetylcholinesterase overexpression mediated by oncolytic adenovirus exhibited potent anti-tumor effect. BMC Cancer 2014, 14, 668-679. [CrossRef] [PubMed]

36. Zhang, X.; Lu, L.; Zhang, X.; Zhang, B.; Wu, J. Synaptic acetylcholinesterase targeted by microRNA-212 functions as a tumor suppressor in non-small cell lung cancer. Int. J. Biochem. Cell Biol. 2013, 45, 2530-2540.

37. Xie, Y.; Zhou, X.; Chen, L.; Zhang, Z.; Wang, C.; Gu, X.; Wang, T.; Peng, X.; Yang, G. Cloning and characterization of a novel sigma-like glutathione S-transferase from the giant panda parasitic nematode, Baylisascaris schroederi. Parasites Vectors 2015, 8, 44-57. [CrossRef]

38. Sturchio, E.; Ficociello, B.; Minoia, C.; Biamonti, G.; Signorini, S.; Moccaldi, A.; Imbriani, M. Gene expression and environmental exposure to xenobiotics: Overview and applications. Giornale Italiano Medicina Lavoro Ergonomia 2008, 30, 101-114.

39. Amelo, W.; Nagpal, P.; Makonnen, E. Antiplasmodial activity of solvent fractions of methanolic root extract of Dodonaea angustifolia in Plasmodium berghei infected mice. BMC Complement. Altern. Med. 2014, 14, 462-469. [CrossRef]

40. Egawa, J.; Ishioka, K.; Ogata, T. Effect of irradiation and chemotherapeutic agents on the capillaries of Ehrlich ascites carcinoma of mice. Acta Radiol. Oncol. Radiat. Phys. Biol. 1979, 18, 535-543. [CrossRef]

41. Mishra, S.; Tamta, A.K.; Sarikhani, M.; Desingu, P.A.; Kizkekra, S.M.; Pandit, A.S.; Kumar, S.; Khan, D.; Raghavan, S.C.; Sundaresan, N.R. Subcutaneous Ehrlich ascites carcinoma mice model for studying cancer-induced cardiomyopathy. Sci. Rep. 2018, 8, 5599-5610. [CrossRef]

42. Mangueira, V.M.; Batista, T.M.; Brito, M.T.; de Sousa, T.K.G.; da Cruz, R.M.D.; de Abrantes, R.A.; Veras, R.C.; de Medeiros, I.A.; de Paula Medeiros, K.K.; da Costa Pereira, A.L.; et al. A new acridine derivative induces cell cycle arrest and antiangiogenic effect on Ehrlich ascites carcinoma model. Biomed. Pharmacother. 2017, 90, 253-261. [CrossRef] [PubMed]

43. Rakesh, K.; Jagadish, S.; Swaroop, T.; Mohan, C.; Ashwini, N.; Harsha, K.; Zameer, F.; Girish, K.; Rangappa, K. Anti-cancer activity of 2,4-disubstituted thiophene derivatives: Dual inhibitors of lipoxygenase and cyclooxygenase. Med. Chem. 2015, 11, 462-472. [CrossRef] [PubMed]

44. Korde Choudhari, S.; Chaudhary, M.; Bagde, S.; Gadbail, A.R.; Joshi, V. Nitric oxide and cancer: A review. World J. Surg. Oncol. 2013, 11, 118-129. [CrossRef] [PubMed]

45. Huerta, S. Nitric oxide for cancer therapy. Futur. Sci. OA 2015, 1, 44-53. [CrossRef] 
46. Melo, P.S.; De Medeiros Cavalcante, H.M.; Barbosa-Filho, J.M.; De Fátima Formiga Melo Diniz, M.; De Medeiros, I.A.; Haun, M. Warifteine and milonine, alkaloids isolated from Cissampelos sympodialis Eichl: Cytotoxicity on rat hepatocyte culture and in V79 cells. Toxicol. Lett. 2003, 142, 143-151. [CrossRef]

47. Organisation for Economic Co-operation and Development (OECD). Guidelines for the Testing of Chemicals: Fish Embryo Acute Toxicity (FET); Test No. 236; OECD: Paris, France, 2013; pp. 1-22.

48. Domingues, I.; Oliveira, R.; Lourenço, J.; Grisolia, C.K.; Mendo, S.; Soares, A.M.V.M. Biomarkers as a tool to assess effects of chromium (VI): Comparison of responses in zebrafish early life stages and adults. Comp. Biochem. Physiol. C Toxicol. Pharmacol. 2010, 152, 338-345. [CrossRef]

49. Organisation for Economic Co-operation and Development (OECD). Guidelines for the Testing of Chemicals: Acute Oral Toxicity; Test No. 423; OECD: Paris, France, 2001; pp. 1-14.

50. Dolai, N.; Karmakar, I.; Suresh Kumar, R.B.; Kar, B.; Bala, A.; Haldar, P.K. Evaluation of antitumor activity and in vivo antioxidant status of Anthocephalus cadamba on Ehrlich ascites carcinoma treated mice. J. Ethnopharmacol. 2012, 142, 865-870. [CrossRef]

51. Santos, J.; Brito, M.; Ferreira, R.; Moura, A.; Sousa, T.; Batista, T.; Mangueira, V.; Leite, F.; Cruz, R.; Vieira, G.; et al. Th1-biased immunomodulation and in vivo antitumor effect of a novel piperine analogue. Int. J. Mol. Sci. 2018, 19, 2594. [CrossRef]

52. Green, L.C.; Wagner, D.A.; Glogowski, J.; Skipper, P.L.; Wishnok, J.S.; Tannenbaum, S.R. Analysis of nitrate, nitrite, and $\left[{ }^{15} \mathrm{~N}\right]$ nitrate in biological fluids. Anal. Biochem. 1982, 126, 131-138. [CrossRef]

53. Finney, D.J. Probit Analysis, 3rd ed.; Cambridge University Press: Cambridge, UK, 1971; p. 1432.

Sample Availability: Samples of the compounds are available from the authors.

(C) 2019 by the authors. Licensee MDPI, Basel, Switzerland. This article is an open access article distributed under the terms and conditions of the Creative Commons Attribution (CC BY) license (http://creativecommons.org/licenses/by/4.0/). 